\title{
フォトダイオードアレー検出器付き高速液体クロマトグラフー 質量分析計による食品中のクチナシ黄色素の分析法
}

(平成 7 年 2 月 13 日受理)

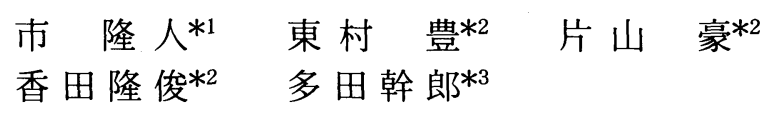

\section{Determination of a Food Colorant, Cardenia Yellow Pigment, in Processed Foods with a High Performance Liquid Chromatograph/Photodiode-array Detector/Mass Spectrometer System}

\author{
Takahito Ichi*1, Yutaka Higashimura*2, Tsuyoshi KataYamA ${ }^{* 2}$, \\ Takatoshi KODA*2 and Mikiro TADA*3
}

(*1 The Graduate School of Natural Science and Technology, Okayama University:

3-1-1, Tsushima-naka, Okayama 700, Japan; *2San-Ei Gen F.F.I., Inc:

1-1-11, Sanwa-cho, Toyonaka, Osaka 561, Japan; *3Department of Biological Function and Genetic Resources Science,

Okayama University: 1-1-1, Tsushima-naka,

Okayama 700 , Japan)

\begin{abstract}
A determination method for a food colorant, gardenia yellow pigment, in processed foods using a high performance liquid chromatograph/photodiode-array detector/mass spectrometer (LC-PDA-MS) system was examined. In this method, the total contents and the composition of crocetin derivatives (the seven main components of gardenia yellow pigment) were measured at the same time in unboiled noodles and dairy beverages to which more than $200 \mu \mathrm{g}$ of gardenia yellow pigment as crocetin per $100 \mathrm{~g}$ of the processed foods had been added. The contents of gardenia yellow pigment in processed foods could be calculated by determining the recovery from model foods

The total contents of gardenia yellow pigment extracted from commercial unboiled noodles and dairy beverages were $3.5 \mu \mathrm{g} / \mathrm{g}$ and $2.3 \mu \mathrm{g} / \mathrm{g}$ as crocetin. From the recoveries (unboiled noodle: $45 \%$, dairy beverage: $62 \%$ ) in these experiments, it was calculated that the commercial unboiled noodle and dairy beverage had been prepared with $750 \mu \mathrm{g}$ and $370 \mu \mathrm{g}$ of gardenia yellow pigment as crocetin per $100 \mathrm{~g}$ of the processed foods, respectively. These values were close to those in the recipe used by the food company. The composition of gardenia yellow pigment from commercial foods was simillar to that of gardenia yellow pigment in the fruit.
\end{abstract}

(Received February 13, 1995)

Key words: クチナシ黄色素 gardenia yellow pigment; 天然着色料 natural food color; クロセチ ン誘導体 crocetin derivative; フォトダイオードアレー検出器付き高速液体クロマトグラフ-質 量分析計 high performance liquid chromatograph/photodiode-array detector/mass spectrometer system

\footnotetext{
*1 岡山大学自然科学研究科: $\overline{7} 700$ 岡山市津島中 3-1-1

*2 三栄源エフ・エフ・アイ(株)：テ561 大阪府豊中市三和町 1-1-11

*3 岡山大学農学部： 7700 岡山市津島中 1-1-1
} 


\section{緒言}

従来，天然添加物は，「天然物は安全である」との理 由に基づいて，その使用についての規制と表示義務はな かったが，平成元年の食品衛生法施行規則の改正によっ て全面表示が義務づけられた，更に，天然添加物の規格 及び使用基準の設定む要求されている 着色に多種の天然色素が使用されているが22 5)，これら の食品用天然着色料についても，その規格の設定が求め られている61.7)

現在使用されている天然由来の食品用着色料のほとん どは，複数の色素成分の混合物である，従って，天然着 色料の規格を設定するためには，それに含まれている構 成成分の個々について，その構造を明らかにし，それら の組成比を知ることが必須となる。また，実際に使用し た食品中での変化についても，個々の成分について理解 することも必要であろう.

著者らは，このような観点から，多くの食品に黄色着 色料として使用されているクチナシ黄色素の構成成分と その組成比を明らかにし，個々の成分の食品化学的性質 を調べて既に報告した ${ }^{8)}$.99，本報告では，クチナシ黄色 素で着色した食品からクチナシ黄色素成分の定性・定量 分析を簡便・かつ正確に行う方法をフォトダイオードア レー検出器付き高速液体クロマトグラフ-質量分析計 (PDA-LC/MS) を用いて検討した。

\section{実験方法}

1. 試

料

1) クチナシ黄色素標準品

三栄源エフ・エフ・アイ(株)の温室で完熟期（結実後 7 か月) まで栽培したクチナシ (Gardenia jasminoides Ellis) 果実を用いて，以下の方法で調製したクロシン黄 色素の画分を“クチナシ黄色素標準品 (Standard Gardenia Yellow Pigment; SGYP)” として使用した。

完熟クチナシ果実に，5倍量の 50\%エタノールを加 え磨砕して, 冷暗所で浸漬抽出を 3 回行い, 次いで, 95\%エタノールを用いて黄色素に由来する色が抽出液 に認められなくなるまで抽出操作を繰り返した，得られ たクチナシ抽出液を合わせて，減圧下， $40^{\circ}$ でエタノー ルを除去した後, 水で希釈して高多孔性吸着樹脂ダイヤ イオンHP-20 カラムに供して黄色素を吸着させ，十分 に水洗した後, $80 \%$ エ夕ノールを流下して溶出してく る黄色素画分を集めた。この溶出液を $40^{\circ}$ で減圧濃縮 し，得られた濃縮物を Sephadex LH-20 カラムに供 し，メタノールで溶出する黄色素画分を集めた．更に純 度を高めるために，この黄色素画分を，そのメ夕ノール 濃度が $30 \%$ になるように水で希釈して，分取用 HPLC に供した．HPLCで分画溶出してくる主要色素成分を 全部集め, 減圧下で溶媒を除去し，真空乾燥して得られ る粉末を“クチナシ黄色素標準品 (SGYP)”として本研 究に使用した。なお，HPLCによる黄色素画分の分取
には，Waters 社製分取システム(PREP 4000)に Sic 社製のデー夕処理機 (Chromatocorder 12) と Waters 社製のフラクションコレクター (WFC) を接続した装置 を利用した。 また，カラムには Nucleosil 5C18( $\mathrm{mm} \times 250 \mathrm{~mm})$ を用い，移動相及びその夕イムプログ ラムは, $10 \mathrm{ml} / \mathrm{min}$ の流速条件で, 0 分から 15 分まで は $50 \%$ メノール，15 分から 30 分にかけてはメ夕 ノール濃度を連続濃度勾配で $50 \%$ から $100 \%$ まで上 昇させ, 30 分以降はメタノールで溶出した。

このようにして調製したクチナシ黄色素標準品は, 後 述するように, その乾燥重量 $1 \mathrm{~g}$ 当たりクロセチン換算 值として $782 \mathrm{mg}$ の総クチナシ黄色素を含有しており, 主要構成成分として 7 種のクロセチン誘導体を含んで いる.

2) 生めん

市販生めん（商品名：中華麺）と実験室で調製した生 めんを使用した。 市販生めんは製造日の夕方に購入し, 1 夜冷蔵庫に保存した後分析に供した。実験室での調製 は市販品之ほぼ同様の方法で行った。すすなお，準強力 粉 $100 \mathrm{~g}$ に, 食塩 $1 \mathrm{~g}$ とクエン酸 $0.53 \mathrm{~g}$ を混合し, こ れに水を $35 \mathrm{~g}$ 添加した後, 練合せてめん帯を形成し, 切断してめん線を作り，ビニール袋に封入した．着色生 めんは，上記の材料にクチナシ黄色素標準品を $880 \mu \mathrm{g}$ （クロセチン換算值として $688 \mu \mathrm{g}$ ）添加して，無添加の 調製品と同様の方法で調製した，従って，このようにし て調製した着色生めん $100 \mathrm{~g}$ 当たりの総クチナシ黄色 素含有量は, クロセチン換算値として, $500 \mu \mathrm{g}$ と算出 される.

\section{3) 乳飲料}

市販乳飲料（商品名：バナナ牛乳）と実験室で調製し た乳飲料を使用した。市販乳飲料は，クチナシ黄色素の 添加が表示してあり，製造日から3日経過したものを 購入し，その日のうちに分析に供した。実験室での乳製 品の調製は，市販製品を模して，以下の方法で行った。 牛乳 $30 \mathrm{~g}$ に, 脱脂粉乳 $2.4 \mathrm{~g}$, 砂糖 $20 \mathrm{~g}$, クエン酸 0.5 $\mathrm{g}$ ，バナナフレーバー $0.2 \mathrm{~g}$ を加え，これに水を加えて 全量を $200 \mathrm{~g}$ にした．次いで，ろ紙でろ過して $100 \mathrm{ml}$ 容量のガラス瓶に分注し，加熱殺菌と冷却の工程を経た 後, 冷蔵庫で眝蔵した。着色乳飲料は, 上記の材料にク チナシ黄色素標準品を $880 \mu \mathrm{g}$ (クロセチン換算値とし て $688 \mu \mathrm{g} ）$ 添加して, 無添加の調製品と同様の方法で 調製した。従って，このようにして調製した着色乳飲料 $100 \mathrm{~g}$ 当たりの総クチナシ黄色素含有量は, クロセチン 換算値として, $340 \mu \mathrm{g}$ と算出される.

\section{2. 食品試料からのクチナシ黄色素の抽出}

生めんの場合, 試料約 $10 \mathrm{~g}$ を正確にひょう取して, これに $50 \%$ アセトンを $100 \mathrm{ml}$ 加えて，乳鉢中で十分 に磨砕混合して $2 \sim 3$ 時間室温暗所で放置した後，ろ紙 （東洋滤紙，No. 5C）を用いて自然ろ過し，得られる約 
$80 \mathrm{ml}$ のろ液を $100 \mathrm{ml}$ に定容した。乳飲料の場合に は，試料約 $10 \mathrm{~g}$ を正確にひょう取して，これに $50 \%$ アセトンを $90 \mathrm{ml}$ 加えて良く振り混ぜて $2 \sim 3$ 時間室温 暗所で放置した．生じた沈殿物をろ紙（東洋濾紙，No. 5C）を用いて自然万過し，得られるろ液を $100 \mathrm{ml}$ に定 容した．以後の操作は両試料共に同じように行った．す なわち, これらの定容溶液から $50 \mathrm{ml}$ を取り, 隇圧下, $40^{\circ}$ でアセトンを留去した後, 油脂分を $n$-ヘキサン 10 $\mathrm{ml}$ で抽出除去してから, その全量を Sep-pakカート リッジC18 (Waters 社製)に供して黄色素を吸着させ た. 続いてカートリッジを蒸留水 $25 \mathrm{ml}$ で水洗した後, $2.5 \mathrm{ml}$ のメタノールで黄色素を溶出させ，これに水を 加えて $5 \mathrm{ml}$ に定容し，この定容溶液を分析供試液とし た.

\section{3. 総クチナシ黄色素の定量}

クチナシ黄色素標準品及び食品試料中の総クチナシ黄 色素含量は, クロセチンの極大吸収波長 $(430 \mathrm{~nm})$ にお ける比吸光係数 $\left(E_{1 \mathrm{~cm}}^{1 \%}=4320\right)^{10)}$ に基づく分光光度法に よって，クロセチン換算值として求めた，溶媒には $80 \%$ メタノールを用い, 吸収スペクトル及び吸光度の 測定は自記分光光度計（(株)日立製作所 U-3200）を使 用した。 また，クチナシ黄色素を構成するクロセチン誘 導体の組成比は HPLC のピーク面積の比で求め, 個々 の成分の量は組成比に含有量を乗じることによって算出 した.

4. フォトダイオードアレー検出器付き高速夜体クロ マトグラフ-質量分析計 (PDA-LC/MS) による各 成分の定性，定量分析

1) 装置

液体クロマトグラフ本体（日本分光：PU-980 型）に フォトダイオードアレー検出器 (日本分光(株): MD910) と四重極型質量分析計 (VG Biotech: PLATFORM 型) 及びデー夕処理機 (Hewlett Packard: VECTRA 286/20N) を連結した装置を使用した。

2) 使用条件

HPLC条件として, カラムには Nucleosil $5 \mathrm{C} 18$ $(\phi 4.6 \mathrm{~mm} \times 250 \mathrm{~mm})$ を用い, 移動相及びその夕イムプ ログラムは, $1.0 \mathrm{ml} / \mathrm{min}$ の流速条件で, 0 分から 15 分 は $50 \%$ メタール, 15 分から 30 分にかけてメタノー ル濃度を連続勾配で $50 \%$ から $100 \%$ まで上昇させ, 30 分以降 40 分までメ夕ノールで溶出した. 黄色素成 分の検出はフォトダイオードアレー検出器で 250 ～500 $\mathrm{nm}$ の波長域で行い，マススペクトルは，イオン化（イ オン源温度 $70^{\circ}$, ネブライザーガス $\left(\mathrm{N}_{2}\right)$ 流量 $10 \mathrm{~L} / \mathrm{hr}$, スキマー電圧 $100 \mathrm{~V})$ にエレクトロ・スプレー・イオ ン化 (ESI) 法を用い，ネガティブモードで測定した。 ま た, スプリッターを $97: 3$ に設定して, 溶出液の 3/ 100 を質量分析計へ，97/100をつォトダイオードア レー検出器に導き, 質量分析計によるマススペクトルの
分析とフォトダイオードアレー検出器による吸収スペク トルの測定は 4 秒間に 1 回の頻度で行った。なお， 1 回 の分析に分析供試液 $20 \mu 1$ を使用した.

3）定性・定量

各成分の同定は, HPLC の保持時間, 吸収スペクト ルの 420 440 nm 付近の極大吸収波長及びマススペク トルによって同定し，シス型の成分に関しては，これら の結果に加えてシスピークである $320 \mathrm{~nm}$ 付近の吸収 の有無によって判定した.

構成色素成分（クロセチン誘導体）の組成比は, 検出 波長 $440 \mathrm{~nm}$ で得られたクロマトグラムから, 相当す る成分のピーク面積の総和に対する個々の成分の比 (\%) として表した。個々の成分の量は, 求めた組成比にあら かじめ「3. 総クチナシ黄色素の定量」に示した分光学 的手法で求めた総含有量を乗じることによって算出し た。

\section{5. 食品中のクロセチン誘導体の耐熱・耐光試験}

実験室で調製した着色生めん之着色乳飲料を用いて, クロセチン誘導体の耐熱性と耐光性を調べた. 着色生め

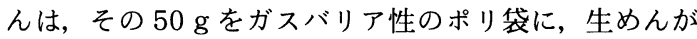
平らな一層になるように入れて真空パックした。着色乳 飲料は, その $100 \mathrm{~g}$ をガラス容器 $(\phi 3.8 \mathrm{~cm} \times 10 \mathrm{~cm})$ に 入れて実験に供した。

耐熱性は $80^{\circ}$ の水浴中で 30 分間及び 120 分間加熱処 理し，耐光性はロングライフフェードメーター（スガ試 験機：FAL-3 型）を用いて，キセノンランプを光源と する光強度（放射光強度： $490 \mathrm{~W} / \mathrm{m}^{2}$ ) の白色光（波長 幅：300〜750 nm）を 2 時間及び 4 時間照射処理した. 生めんについては, 照射中 1 時間ごとに裏返して, 試 料への均一照射を図った。処理前後のクロセチン誘導体 の総量及び個々の成分の量の変化をPDA-LC/MS を用 いて求めた。なお，すべての実験はいずれも 5 回連続 して行い，その平均值を採用した。

\section{結果及び考察}

1. クチナシ黄色素標準品のクロセチン誘導体の総含 有量及び組成比

クチナシ黄色素標準品の濃度が， $1.0 \mu \mathrm{g} / \mathrm{ml}$ になるよ うに調製した $80 \%$ メタール溶液の $430 \mathrm{~nm}$ での吸光 度は，0.338であった。この結果とクロセチンの比吸光 係数 $\left(E_{1 \mathrm{~cm}}^{1 \%}=4320\right)^{10)}$ に基づき, 調製したクチナシ黄色 素標準品の色素純度は $78.2 \%$ であると算出した。次い で，主要構成成分の同定と組成比を PDA-LC/MS を用 いて調べた。得られた 3 次元 HPLC パターン, $440 \mathrm{~nm}$ でのモニターによる 2 次元 HPLC パターン, 各ピーク 成分の吸収スペクトル及びマススペクトルを Fig. 1〜4 に示した. 2 つの HPLC パターン (Fig. 1，2) から, ク チナシ黄色素標準品には主要構成成分として 7 種 (P-1 〜P-7) が存在していることが認められ，更に，これら の構成成分のうち P-4 と P-7 は吸収スペクトル (Fig. 3) 
にシス異性体であることに由来する明確なシスピーク $(321 \mathrm{~nm}$ と $314 \mathrm{~nm})$ が認められた. また. P-1〜 P-7 マススペクトル (Fig. 4) の脱プロトン化分子 ([M-H] $\left.]^{-}\right)$ は，それぞれ $m / z 975,813,651,651,651,489,489$ に出現し, すべての構成成分にクロセチンに由来するフ ラグメントイオン $m / z 327$ が観察された. 各成分の分 子量は極性が低下するに伴って，グルコースに相当する 質量, すなわち 162 ずつ段階的に減少していた。これ らの吸収スペクトルとマススペクトルの結果を前報8) の結果と比較することによって，この 7 成分を同定す ることができた。これらの結果を溶出順に付した略記号 (P-1〜7) 及びデー夕処理によって求めたクチナシ黄色素 標準品中の主要構成成分の組成比と共に, Table 1 に示 した.なお，その組成比は前報8で測定した完熟果実の 組成比の結果に近似したあのであった.

\section{2. 検量線及び検出限界}

クチナシ黄色素標準品を用いて種々のクチナシ黄色素 濃度 $(0.2 \sim 8.0 \mu \mathrm{g} / \mathrm{ml}$; クロセチン換算) に調製した色

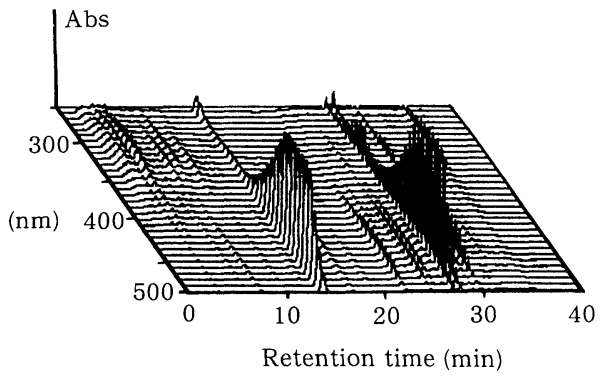

Fig. 1. 3D-HPLC pattern of crocetin derivatives in SGYP

Column: Nucleosil 5C18 $(\phi 4.6 \mathrm{~mm} \times 250$ $\mathrm{mm}$ ); flow rate: $1 \mathrm{ml} / \mathrm{min}$

Detector: photodiode-array $(250 \sim 500$ nm; Nippon Bunko 980)

Solvent: $0-15 \min (50 \% \mathrm{MeOH}) \rightarrow 15-$ $30 \mathrm{~min} \quad(50-100 \% \mathrm{MeOH}$; linear gradient $\rightarrow$ 30-40 $\min (100 \% \mathrm{MeOH})$
素液を PDA-LC/MS に供して, 検出波長 $440 \mathrm{~nm}$ で得 られた 7 成分のピーク面積の総和と濃度の関係を求め た結果, 色素濃度が $1 \sim 8 \mu \mathrm{g} / \mathrm{ml}$ の範囲で原点を通る良 好な直線が得られた。 そして，この濃度範囲で 7 種の クロセチン誘導体の組成比も再現性良く得られた。 しか し, $1 \mu \mathrm{g} / \mathrm{ml}$ より低い濃度では, 求めた組成比の再現 性が悪く, 従って, 定量值にも信頼性が無くなった.こ れらの結果から, 分析供試液のクチナシ黄色素濃度がク ロセチン換算量として, $1 \mu \mathrm{g} / \mathrm{ml}$ 以上であれば, その $20 \mu \mathrm{l}$ を使用することによって，7種の主要構成成分の 組成比を求めることができ，また，それらの $440 \mathrm{~nm}$ で得られたクロマトグラムのピーク総面積から, クチナ シ黄色素量の定量が可能であることが明らかになった。

\section{3. クチナシ黄色素の添加回収実験}

着色された食品中よりクチナシ色素量を求めるときに は, あらかじめその回収率を求めることが重要である. そこで, 実験室で, クチナシ黄色素標準品をそれぞれの

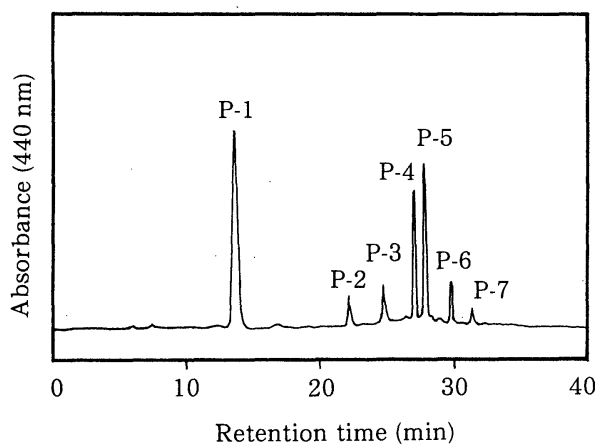

Fig. 2. HPLC pattern of crocetin derivatives in SGYP

Column: Nucleosil $5 \mathrm{C} 18(\phi 4.6 \mathrm{~mm} \times 250$ $\mathrm{mm}$ ); flow rate: $1 \mathrm{ml} / \mathrm{min}$

Detector: photodiode-array $(440 \mathrm{~nm}$; Nippon Bunko 980)

Solvent: $0-15 \min (50 \% \mathrm{MeOH}) \rightarrow 15-$ $30 \mathrm{~min} \quad(50-100 \% \mathrm{MeOH}$; linear gradient $\rightarrow 30-40 \min (100 \% \mathrm{MeOH})$

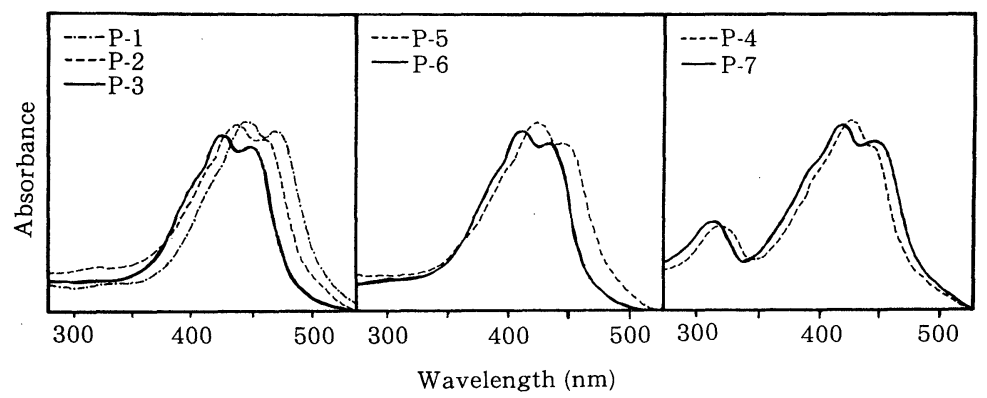

Fig. 3. UV spectra of crocetin derivatives in SGYP P-1 P- 7 see Table 1 
試料 $100 \mathrm{~g}$ 当たり, 生めんには $640 \mu \mathrm{g}$ （クロセチン換 算量: $500 \mu \mathrm{g}$ ), 乳飲料には $440 \mu \mathrm{g}$ （クロセチン換算: $340 \mu \mathrm{g})$ を添加して調製した生めんと乳飲料を用い, 一連の操作を行って分析供試液を調製して回収実験を 行った.

その結果を, PDA-LC/MS による主要構成成分の組 成比の分析結果之共に Table 2 に示した。 分析供試液 中の総クチナシ黄色素量を分光学的方法によって測定し
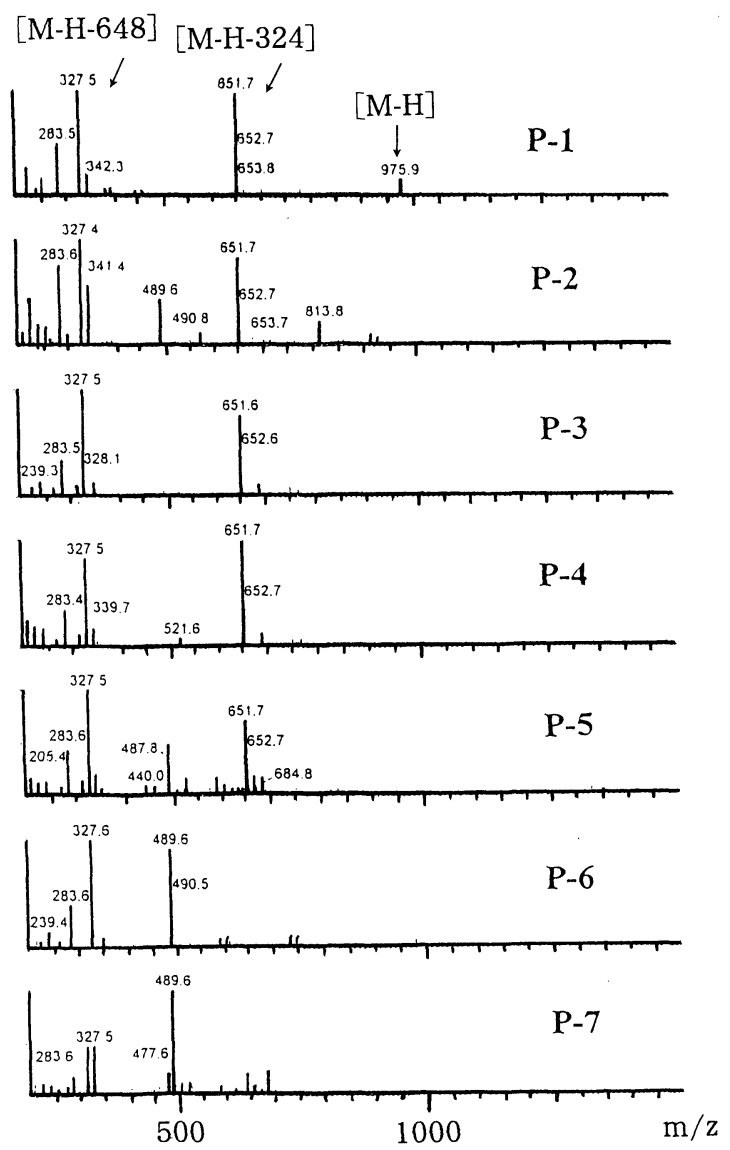

Fig. 4. Mass spectra of crocetin derivatives in SGYP
た回収率は, 生めんが $45.0 \%$, 乳飲料が $66.2 \%$ で, 5 回連続の実験結果加ら求めた变動係数 (\%)（標準偏差/ 平均值 $\times 100 ）$ は，それぞれ， $5.0 \% ， 3.4 \%$ であった。 なお，上記の検出波長 $440 \mathrm{~nm}$ で得られたピーク総面 積と濃度の関係の検量線に基づいて算出した平均回収率 は, 生めんについては $44.2 \%$, 乳飲料は $64.4 \%$ で, 分 光学的方法での結果との間に大差は無く, 検量線の有効 性が確認された。

また，PDA-LC/MSによる主要構成成分の組成比の 分析結果より, 生めん, 乳飲料とも添加したクチナシ黄 色素標準品の組成 (P-1: 65.3\%, P-2: 4.5\%, P-3: 3.1\%, P-4: 8.8\%, P-5: 12.4\%, P-6: 3.3\%, P-7: 0.4\%) と極めて近似していた．これらのことは, 添加したクチ ナシ黄色素中の特定の成分が食品製造中に特異的に変化 していないこと，また，すべての成分が同じ割合で抽出 されていると考えられた。 また，食品の着色に使用した

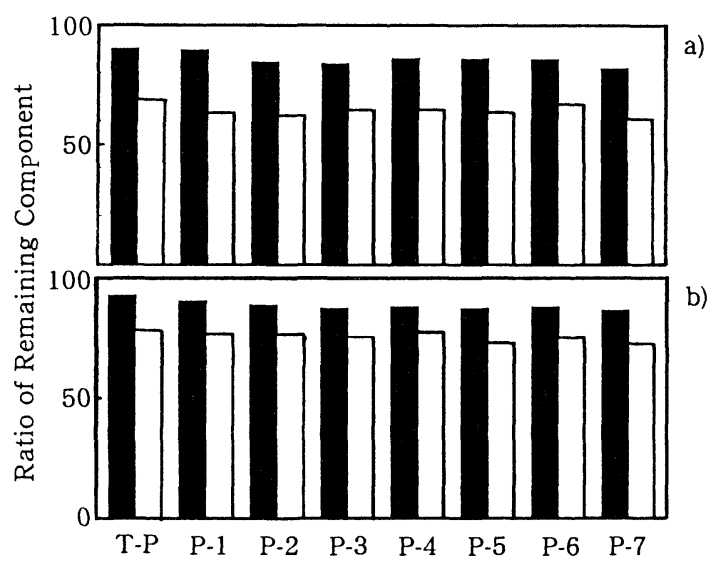

Fig. 5. Heat stability of crocetin derivatives in unboiled noodle and dairy beverage prepared in laboratory

a): unboiled noodle; b): dairy beverage

口: $80^{\circ} \mathrm{C}, 30 \mathrm{~min}$; $\square: 80^{\circ} \mathrm{C}, 120 \mathrm{~min}$ (in dark)

T-P: SGYP

Table 1. Structure and Composition of Crocetin Derivatives in SGYP ${ }^{1)}$

\begin{tabular}{clc}
\hline \hline Symbol & \multicolumn{1}{c}{ Structure } & Composition (\%) \\
\hline P-1 & Crocetin-digentiobioside ester (trans): crocin & 65.26 \\
P-2 & Crocetin-monogentiobioside-monoglucoside ester (trans) & 4.52 \\
P-3 & Crocetin-monogentiobioside ester (trans) & 3.06 \\
P-4 & Crocetin-monogentiobioside ester (cis) & 8.75 \\
P-5 & Crocetin-diglucoside ester (trans) & 12.44 \\
P-6 & Crocetin-monoglucoside ester (trans) & 3.32 \\
P-7 & Crocetin-monoglucoside ester (cis) & 0.38 \\
\hline
\end{tabular}

1) Standard Gardenia Yellow Pigment 
Table 2. Recoveries of Crocetin Derivatives from Unboiled Noodle and Dairy Beverage Prepared in Laboratory

\begin{tabular}{|c|c|c|c|c|c|c|c|c|c|c|c|c|}
\hline \multirow[t]{2}{*}{ Sample } & \multirow[t]{2}{*}{ No. } & \multicolumn{4}{|c|}{$\begin{array}{l}\text { Extracted total pigments }(\mu \mathrm{g} / \mathrm{g}) \\
\text { (Recovery \%) }\end{array}$} & \multicolumn{7}{|c|}{ Composition (\%) } \\
\hline & & \multicolumn{2}{|c|}{ Method $1^{\text {a) }}$} & \multicolumn{2}{|c|}{ Method $2^{\mathrm{b})}$} & \multirow{2}{*}{$\frac{P-1}{65.4}$} & \multirow{2}{*}{$\frac{\mathrm{P}-2}{4.1}$} & \multirow{2}{*}{$\frac{\mathrm{P}-3}{3.1}$} & \multirow{2}{*}{$\frac{P-4}{8.7}$} & \multirow{2}{*}{$\frac{P-5}{12.5}$} & \multirow{2}{*}{$\frac{P-6}{3.0}$} & \multirow{2}{*}{$\frac{P-7}{0.4}$} \\
\hline \multirow{6}{*}{$\begin{array}{l}\text { Unboiled } \\
\text { noodle }\end{array}$} & 1 & 2.26 & $(45.2)$ & 2.18 & $(42.0)$ & & & & & & & \\
\hline & 2 & 2.18 & $(43.6)$ & 2.26 & $(45.2)$ & 65.7 & 4.4 & 3.2 & 9.0 & 12.4 & 3.1 & 0.4 \\
\hline & 3 & 2.22 & $(44.4)$ & 2.09 & $(41.8)$ & 64.3 & 4.5 & 3.2 & 8.7 & 12.8 & 3.1 & 0.4 \\
\hline & 4 & 2.38 & $(47.6)$ & 2.28 & $(45.6)$ & 64.9 & 4.5 & 3.3 & 8.9 & 12.6 & 3.2 & 0.4 \\
\hline & 5 & 2.21 & $(44.2)$ & 2.31 & $(46.2)$ & 66.7 & 4.5 & 3.2 & 8.7 & 12.7 & 3.1 & 0.4 \\
\hline & $X \pm \sigma^{c)}$ & $2.25 \pm 0.07$ & $(45.0)$ & $2.22 \pm 0.08$ & $(44.2)$ & 65.3 & 4.4 & 3.2 & 8.8 & 12.6 & 3.1 & 0.4 \\
\hline \multirow{6}{*}{$\begin{array}{l}\text { Dairy } \\
\text { beverage }\end{array}$} & 1 & 2.28 & $(67.1)$ & 2.22 & $(65.3)$ & 65.3 & 4.4 & 3.2 & 8.8 & 12.2 & 3.0 & 0.4 \\
\hline & 2 & 2.20 & $(64.7)$ & 2.18 & $(64.1)$ & 64.8 & 4.5 & 3.2 & 8.8 & 12.3 & 3.1 & 0.4 \\
\hline & 3 & 2.34 & $(68.8)$ & 2.12 & (62.4) & 65.5 & 4.2 & 3.3 & 9.0 & 12.1 & 3.1 & 0.4 \\
\hline & 4 & 2.26 & $(66.5)$ & 2.16 & (63.5) & 64.5 & 4.2 & 3.1 & 8.9 & 12.0 & 3.2 & 0.4 \\
\hline & 5 & 2.17 & $(63.8)$ & 2.27 & $(66.8)$ & 64.4 & 4.2 & 3.2 & 9.0 & 12.4 & 3.1 & 0.4 \\
\hline & $X \pm \sigma^{\mathrm{c})}$ & $2.25 \pm 0.06$ & $(66.2)$ & $2.19 \pm 0.05$ & $(64.4)$ & 64.9 & 4.3 & 3.2 & 8.9 & 12.2 & 3.1 & 0.4 \\
\hline
\end{tabular}

Table 3. Light Stability of Crocetin Derivatives in Unboiled Noodle and Dairy Beverage Prepared in Laboratory

\begin{tabular}{|c|c|c|c|c|c|c|c|c|c|}
\hline \multirow{2}{*}{ Sample } & \multirow{2}{*}{$\begin{array}{l}\text { Light } \\
\text { treatment } \\
\text { (hr) }\end{array}$} & \multirow{2}{*}{$\begin{array}{l}\text { Extracted } \\
\text { total } \\
\text { pigments } \\
(\mu \mathrm{g} / \mathrm{g})\end{array}$} & \multicolumn{7}{|c|}{$\begin{array}{l}\text { Crocetin derivatives } \\
\text { (Composition \%) }\end{array}$} \\
\hline & & & P-1 & P-2 & P-3 & $\mathrm{P}-4$ & P-5 & P-6 & P-7 \\
\hline \multirow{3}{*}{$\begin{array}{c}\text { Unboiled } \\
\text { noodle }\end{array}$} & 0 & $\begin{array}{c}3.09 \\
{[100]}\end{array}$ & $\begin{array}{c}1.94 \\
(62.8) \\
{[100]}\end{array}$ & $\begin{array}{c}0.10 \\
(3.2) \\
{[100]}\end{array}$ & $\begin{array}{c}0.09 \\
(3.0) \\
{[100]}\end{array}$ & $\begin{array}{c}0.28 \\
(9.1) \\
{[100]}\end{array}$ & $\begin{array}{c}0.32 \\
(10.3) \\
{[100]}\end{array}$ & $\begin{array}{c}0.11 \\
(3.6) \\
{[100]}\end{array}$ & $\begin{array}{c}0.01 \\
(0.3) \\
{[100]}\end{array}$ \\
\hline & 2 & $\begin{array}{c}1.52 \\
{[49.2]}\end{array}$ & $\begin{array}{c}1.00 \\
(65.7) \\
{[51.46]}\end{array}$ & $\begin{array}{c}0.05 \\
(3.41) \\
{[52.42]}\end{array}$ & $\begin{array}{c}0.05 \\
(3.23) \\
{[52.96]}\end{array}$ & $\begin{array}{c}0.12 \\
(8.22) \\
{[44.43]}\end{array}$ & $\begin{array}{c}0.03 \\
(2.28) \\
{[10.89]}\end{array}$ & $\begin{array}{c}0.02 \\
(1.0) \\
{[14.48]}\end{array}$ & $\begin{array}{c}0.01 \\
(0.11) \\
{[18.04]}\end{array}$ \\
\hline & 4 & $\begin{array}{l}0.58 \\
{[18.8]}\end{array}$ & $\begin{array}{c}0.44 \\
(76.3) \\
{[22.81]}\end{array}$ & $\begin{array}{c}0.02 \\
(3.95) \\
{[23.17]}\end{array}$ & $\begin{array}{c}0.02 \\
(3.74) \\
{[23.40]} \\
\end{array}$ & $\begin{array}{c}0.05 \\
(8.82) \\
{[18.19]} \\
\end{array}$ & $\begin{array}{c}0.01 \\
(0.58) \\
{[1.06]}\end{array}$ & $\begin{array}{c}0.01 \\
(0.23) \\
{[1.20]}\end{array}$ & $\begin{array}{c}0.01 \\
(0.01) \\
{[0.63]}\end{array}$ \\
\hline \multirow{3}{*}{$\begin{array}{l}\text { Dairy } \\
\text { beverage }\end{array}$} & 0 & $\begin{array}{l}2.24 \\
{[100]} \\
\end{array}$ & $\begin{array}{l}1.41 \\
(62.8) \\
{[100]}\end{array}$ & $\begin{array}{c}0.07 \\
(3.2) \\
{[100]}\end{array}$ & $\begin{array}{c}0.07 \\
(3.0) \\
{[100]}\end{array}$ & $\begin{array}{c}0.20 \\
(9.1) \\
{[100]} \\
\end{array}$ & $\begin{array}{c}0.23 \\
(10.3) \\
{[100]}\end{array}$ & $\begin{array}{c}0.08 \\
(3.6) \\
{[100]}\end{array}$ & $\begin{array}{c}0.01 \\
(0.3) \\
{[100]}\end{array}$ \\
\hline & 2 & $\begin{array}{l}1.34 \\
{[60.0]}\end{array}$ & $\begin{array}{c}0.88 \\
(65.7) \\
{[62.58]}\end{array}$ & $\begin{array}{c}0.04 \\
(3.22) \\
{[60.20]}\end{array}$ & $\begin{array}{c}0.04 \\
(2.99) \\
{[59.62]}\end{array}$ & $\begin{array}{c}0.11 \\
(8.22) \\
{[54.04]}\end{array}$ & $\begin{array}{c}0.03 \\
(2.12) \\
{[12.31]}\end{array}$ & $\begin{array}{c}0.01 \\
(0.95) \\
{[15.79]}\end{array}$ & $\begin{array}{c}0.01 \\
(0.08) \\
{[13.12]}\end{array}$ \\
\hline & 4 & $\begin{array}{c}0.56 \\
{[25.0]}\end{array}$ & $\begin{array}{c}0.43 \\
(76.3) \\
{[30.37]}\end{array}$ & $\begin{array}{c}0.02 \\
(3.95) \\
{[30.86]}\end{array}$ & $\begin{array}{c}0.02 \\
(3.74) \\
{[31.17]}\end{array}$ & $\begin{array}{c}0.05 \\
(8.82) \\
{[24.23]}\end{array}$ & $\begin{array}{c}0.01 \\
(0.58) \\
{[1.41]}\end{array}$ & $\begin{array}{c}0.01 \\
(0.23) \\
{[1.16]}\end{array}$ & $\begin{array}{c}0.01 \\
(0.01) \\
{[0.83]}\end{array}$ \\
\hline
\end{tabular}

[ ] Ratio of remaining component (\%) 
Table. 4. Determination of Crocetin Derivatives Extracted from Commercial Foods

\begin{tabular}{|c|c|c|c|c|c|c|c|c|c|}
\hline \multirow{2}{*}{ Sample } & \multicolumn{2}{|c|}{$\begin{array}{l}\text { Extracted total } \\
\text { pigments }(\mu \mathrm{g} / \mathrm{g})\end{array}$} & \multicolumn{7}{|c|}{ Composition (\%) } \\
\hline & No. & Method $1^{\text {a) }}$ & P-1 & P-2 & P-3 & P-4 & P-5 & P-6 & P-7 \\
\hline \multirow{6}{*}{$\begin{array}{c}\text { Unboiled } \\
\text { noodle }\end{array}$} & 1 & 3.44 & 66.3 & 4.5 & 3.7 & 9.3 & 5.6 & 1.8 & 0.2 \\
\hline & 2 & 3.68 & 68.2 & 4.4 & 3.9 & 9.0 & 4.3 & 2.3 & 0.2 \\
\hline & 3 & 3.71 & 67.5 & 4.5 & 3.6 & 9.1 & 4.2 & 1.7 & 0.2 \\
\hline & 4 & 3.31 & 67.1 & 4.6 & 3.4 & 8.8 & 4.8 & 1.9 & 0.2 \\
\hline & 5 & 3.41 & 67.4 & 4.5 & 3.4 & 8.8 & 5.5 & 2.4 & 0.2 \\
\hline & $X \pm \sigma^{b)}$ & $3.51 \pm 0.16$ & 67.3 & 4.5 & 3.6 & 9.0 & 4.9 & 2.0 & 0.2 \\
\hline \multirow{6}{*}{$\begin{array}{l}\text { Dairy } \\
\text { beverage }\end{array}$} & 1 & 2.41 & 66.4 & 4.9 & 4.2 & 8.7 & 4.3 & 1.8 & 0.1 \\
\hline & 2 & 2.15 & 64.1 & 5.1 & 3.5 & 8.8 & 4.4 & 1.7 & 0.1 \\
\hline & 3 & 2.22 & 65.5 & 4.4 & 3.8 & 8.7 & 4.7 & 2.2 & 0.1 \\
\hline & 4 & 2.35 & 66.3 & 4.6 & 3.9 & 9.2 & 4.6 & 2.5 & 0.1 \\
\hline & 5 & 2.37 & 66.7 & 4.5 & 4.1 & 9.1 & 4.5 & 1.8 & 0.1 \\
\hline & $X \pm \sigma^{\mathrm{b})}$ & $2.30 \pm 0.10$ & 65.8 & 4.7 & 3.9 & 8.9 & 4.5 & 2.0 & 0.1 \\
\hline
\end{tabular}

a) Determination based on spectophotometry

b) Means \pm standard deviation

クチナシ黄色素とクチナシ黄色素標準品との違い屯判断 でき，また，添加したクチナシ黄色素の品質む判断でき ると考えられた.

\section{4. 食品中におけるクチナシ色素の熱及び光による変 化}

著者らは, Mcllvaine 緩衝液 $(\mathrm{pH}=7.0)$ を用いた以前 の実験 ${ }^{9)}$ で, クチナシ黄色素は高い耐熱性を有している が，耐光性は低いことを明らかにした．そこで，実験室 で調製した着色生めんと着色乳飲料をモデルとして用い て, 実際の食品中でのクチナシ黄色素の熱及び光に対す る安定性をPDA-LC/MS で調べた。なお，これらの実 験における総クチナシ色素量は分光学的方法で求めた.

耐熱性試験の結果は Fig. 5 に各色素成分の残存率で 示した. 生めんと乳飲料の両者において, クチナシ黄色 素の主要構成成分である 7 種のクロセチン誘導体のい ずれも，30 分の熱処理による減少は $5 \%$ 程度に過ぎ ず, 120 分の処理においても 85\% 以上の色素残存率を 示し, 食品中においてもクチナシ黄色素の高い耐熱性が 示された.

耐光性試験の結果は Table 3 に, クチナシ黄色素の 総クチナシ色素量及び 7 種のクロセチン誘導体個々の 量と共に，その組成比を（）内，各色素の残存率を [ ] 内に\%で示した. 総クチナシ色素量及び個々のク ロセチン誘導体の量が光照射時間に依存して減少し, ク チナシ黄色素は耐光性にそしいことが明らかに示され た. また, 色素残存率の変化から, クロセチン母核にゲ ンチオビオースがエステル結合している成分 $(\mathrm{P}-1 \sim \mathrm{P}-4)$ とその他の成分 (P-5〜P-7) の耐光性には差があり, こ れが光照射による組成比の変化をむたらしていることが
分かった。 言い換えると, 後者の成分 (P-5〜P-7) は前 者に比べて光感受性が高く, このことは前報9)での結果 と一致した。

\section{5. 市販品への適用}

市販品のクチナシ黄色素使用表示のある生めん及び乳 飲料各 1 種, それぞれ 5 検体について PDA-LC/MS を 用いて分析を行った結果を Table 4 に示した. 生めん 及び乳飲料から検出されたクチナシ色素量は, それぞれ 検体 $100 \mathrm{~g}$ 当たり，クロセチン換算として $350 \mu \mathrm{g}, 230$ $\mu \mathrm{g}$ であった. 更に, 5 回連続の実験結果より求めたク チナシ黄色素量の変動係数は, それぞれ $4.6 \%, 4.3 \%$ と良好な再現性を示し，本方法の食品への使用の有用性 を示している.

「3. クチナシ黄色素の添加回収実験」で得たそれぞれ の回収率（生めん $45.0 \%$, 乳飲料 $66.2 \%$ ）を採用する と, 市販の生めん及び乳飲料の製造には, 製品 $100 \mathrm{~g}$ 当たりクロセチン換算值として $750 \mu \mathrm{g}, 370 \mu \mathrm{g}$ の濃度 のクチナシ黄色素が使用されたことが推測された.これ らの値は, 食品製造会社が用いる生めん及び乳飲料の一 般処方の添加量と良く一致していた.

また, 抽出されたクチナシ黄色素中の構成成分は両者 ともにクチナシ黄色素標準品の組成比と近似したもので あり，市販食品に使用されたクチナシ黄色素の品質は良 好なものであると考えられ，また，製造工程及び流通で の変化も少ないことが推察された。

\section{ま とめ}

食品中のクチナシ黄色素の定量, 定性分析にフォトダ イオードアレー検出器付き高速液体クロマトグラフ-質 量分析計を用いる方法を検討した，本方法では，色素成 
分をマススペクトルの測定及びフォトダイオードアレー 検出器による吸収スペクトルにより定性分析を行い，検 出波長 $440 \mathrm{~nm}$ で得られたクロマトグラムより定量分 析を行うことによって, 1 回の分析で定性・定量分析を 簡便に行うことができる.

この方法を用いて, クチナシ黄色素で着色した市販の 生めん及び乳飲料について調べた. その結果, それぞれ 製品 $100 \mathrm{~g}$ 当たり, クロセチン換算量として $350 \mu \mathrm{g}$, $230 \mu \mathrm{g}$ が検出され, また, 主要構成成分の組成比は, クチナシ黄色素標準品のそれと近似していた。これらの 值をモデル食品で得た回収率（生めん $45.0 \%$, 乳飲料 62.2\%) で補正すると, 市販の生めん及び乳飲料中で は, それぞれ食品 $100 \mathrm{~g}$ 当たり $750 \mu \mathrm{g}, 370 \mu \mathrm{g}$ のクチ ナシ黄色素を使用し製造したことが推定された。これら の值は, 食品製造会社が用いる生めん及び乳飲料の一般 処方の添加量と良く一致していた. また, 抽出されたク チナシ黄色素中の構成成分は両者とあにクチナシ黄色素 標準品の組成比と近似していた.

以上の結果から，あらかじめモデル食品を用いて回収
率を求めておくことによって, 食品に添加されたクチナ シ黄色素中の各成分量と組成比を調べることができた.

文献

1) 佐々木弥生：食衛誌. 33, 516 517 (1992).

2) 西島基弘：同上 33, 515 516 (1992).

3) 長南隆夫：同上 33, 517 (1992).

4) 山田貞二：同上 33, 518 519 (1992).

5) 岸 弘子: 同上 33, 519 520 (1992).

6) 清水孝重, 中村幹雄, 藤井正美監修: “概説 食用天然色 素” p.3 36 (1993) 光琳.

7) 谷村顕雄, 片山 修, 遠藤英美, 黒川和男, 吉積智司: “天然着色料ハンドブック” p. 212〜232 (1979) 光琳.

8) 市 隆人, 東村 豊, 片山 豪, 香田隆俊, 多田幹郎: 日食工誌. 印刷中.

9) 市 隆人, 東村 豊, 片山 豪, 香田隆俊, 多田幹郎: 同上, 印刷中.

10) Davies, B, H.: "Chemistry and Biochemistry of Plant Pigments”, ed. by Goodwin, T. W., p. 149 (1975) Academic Press. 